\title{
Effect of gonadotrophins on the ovarian interstitial tissue of the wood mouse, Apodemus sylvaticus
}

\author{
J. Clarke and F. Brook \\ Department of Zoology, Oxford University, South Parks Road, Oxford OX1 3PS, UK
}

The ovarian interstitial tissue of the wood mouse (Apodemus sylvaticus) is extensively developed. The effect of equine chorionic gonadotrophin (eCG) and human chorionic gonadotrophin (hCG) on ovarian interstitial tissue was investigated in wood mice from a laboratory stock. The tissue was assessed by measuring the relative size of the cells, cell nucleus diameter and (in adults) nuclear shape. Hormone-treated wood mice had larger interstitial cells and larger cell nuclei than untreated animals. In addition, the cell nuclei of adult hormonetreated wood mice had a smooth round or oval outline, whereas those of untreated animals had an irregular outline with spiky projections. Electron microscopy showed that the irregular spiky outline of the cell nuclei in untreated wood mice was caused by distortions of the nuclear membrane by a large number of intracellular lipid droplets; the droplets were less abundant in the hormonetreated animals. These experiments indicate that the cells of the interstitial tissue of the wood mouse are under the control of gonadotrophins, and that these cells are likely to be a site of the synthesis and release of steroid hormones. The methods used in this study to assess the state of the cells could be applied to animals from the field to investigate the role of interstitial tissue in the reproductive biology of wood mice.

\section{Introduction}

Bouin (1902) recognized that the 'glande interstitielle' of mammalian ovaries varies considerably in its development. In some groups (rodents, insectivores, bats) between 80 and $90 \%$ of an ovary comprises interstitial tissue, whereas in other groups ('mammifères supérieurs' and women) the tissue is poorly developed. From the general structure of the interstitial gland and from the characteristics of its cells (in which large numbers of lipid granules occur), Bouin deduced that it is a gland of internal secretion. In the wood mouse (Apodemus sylvaticus), the interstitial tissue is extensively developed and constitutes at least 55\% of the adult ovary (Brook and Clarke 1989; J. Clarke, unpublished), which is a similar percentage to that seen in rabbits (Deanesley, 1972). The accumulation of lipid in the interstitial cells and the extensive development of the tissue seen in the wood mouse are also observed in rabbits, guinea-pigs, rats, hamsters, cats, a hare Lepus nigricollis, a bat Myotis grisescens, and the civet cat Paradoxurus hermaphroditus, although the large size of the lipid droplets $(1.5 \mu \mathrm{m}$ diameter) appears unique to the wood mouse (Guraya, 1978; Brook and Clarke, 1989). The lipid includes cholesterol and its esters, and $3 \beta$ hydroxysteroid dehydrogenase is also present in the cells, which have smooth endoplasmic reticulum and rounded mitochondria with tubular cristae. These characteristics indicate that the interstitial tissue is an important source of steroid hormones or their precursors (Brook and Clarke, 1989). Guraya and Motta (1980) advocated investigation of the interstitial tissue of seasonally breeding mammals to establish whether it shows seasonal changes. These studies could lead to a better understanding of its role in reproduction. In the present study the response of the interstitial cells of wood mice from a laboratory stock (Clarke, 1985) to exogenous gonadotrophins was investigated. The highly controlled nature of these experiments should facilitate judgements on how the tissue might be investigated in wood mice from the field.

\section{Materials and Methods}

Animals were obtained from a breeding colony of wood mice established in 1976, maintained originally in the former Department of Agricultural Science, Oxford University, and later transferred to the Department of Zoology, Oxford University. The breeding colony and the experimental animals were housed in plastic cages $(42 \mathrm{~cm}$ $\times 26 \mathrm{~cm} \times 11 \mathrm{~cm}$ ) with sawdust and non-absorbent cotton wool for bedding. The mice were supplied ad libitum with Dixon's diet 41 B (Dixon and Sons, Ware, Hertford) and water. With the exception of the adults used in Expt 3 (see below), all animals were maintained on a $16 \mathrm{~h}$ light: $8 \mathrm{~h}$ dark photoperiod at $19 \pm 1{ }^{\circ} \mathrm{C}$.

Email: john.clarke@zoo.ox.ac.uk 


\section{Experiments}

In wood mice from the laboratory stock, the prepurbertal state lasted approximately 2 months. By that stage approximately $90 \%$ of the animals had perforate vaginas. However, $10 \%$ of virgin adult females from the laboratory stock had non-perforate vaginas for many months, threadlike poorly vascularized uteri and ovaries that lacked corpora lutea (Clarke, 1985). Preliminary trials using such animals showed that doses of 10-20 iu equine chorionic gonadotrophin (eCG) or human chorionic gonadotrophin (hCG) once a day for 3 days produced a substantial enlargement of the ovaries and uteri, which were of similar mass to those organs of virgin sexually mature animals that had oestrous cycles or permanently cornified vaginal smears, and represented about $45 \%$ of the virgin animals in the laboratory stock (Clarke, 1985).

Females in Expt 1 were prepubertal and had non-perforate vaginas, whereas those in Expt 2 were selected from the virgin adults in which the vagina remains non-perforate for many months (see above). Juveniles and adults that had non-perforate vaginas were used in these two experiments because it was expected that their ovaries would not be fully active. Therefore, treatment with exogenous gonadotrophins might produce a clear cut response in the interstitial cells. Experiment 3 simulated the transition from the winter non-breeding season to the spring and summer breeding season, which occurs under field conditions (Baker, 1930). Initially, all females used in Expt 3 were sexually mature and had vaginal smears that contained a large number of cornified epithelial cells. These females were transferred for 4 months from the animal house to simulated winter conditions in a cold room at $2{ }^{\circ} \mathrm{C}$ with a photoperiod of $6 \mathrm{~h}$ light:18 $\mathrm{h}$ dark to reduce the secretory activity of the ovaries. The expectation was that gonadotrophin treatment would induce changes in the ovaries similar to those that occur in the wild as the animals change from the non-breeding to the breeding condition. These may include clear cut changes in the interstitial cells.

Injections of eCG and hCG (Sigma-Aldrich, Poole, Dorset) were administered s.c. in $0.1 \mathrm{ml}$ distilled water. Control animals were given $0.1 \mathrm{ml}$ distilled water.

In Expt 1, 12 wood mice aged 20-22 days and weighing $9.9 \pm 0.4 \mathrm{~g}$ were arranged into four blocks each of three comparable animals which were allotted randomly to three treatments: 20 iu eCG on day 1 and 20 iu hCG on day 3 ; 10 iu eCG on day 1 and 10 iu hCG on day 3; and distilled water on the same days. Injections were administered at 12:00 h. In Expt 2, 20 wood mice aged 5-6 months and weighing $15.8 \pm 0.4 \mathrm{~g}$ were arranged into five blocks, each of four comparable animals which were allotted randomly to the four treatments: 10 iu eCG; 10 iu hCG; 10 iu eCG plus 10 iu hCG; and distilled water. In Expt 3, eight wood mice weighing $17.0 \pm 0.5 \mathrm{~g}$ and which, from the age of 6-7 months, had been kept in artificial winter conditions for 4 months (see above) were arranged in four blocks, each of two comparable animals which were allotted randomly to the two treatments: 10 iu eCG plus 10 iu hCG; and distilled water. In Expt 2 and 3, injections were administered at 09:00-10:00 $\mathrm{h}$ and 21:00-22.00 $\mathrm{h}$ for 3 days.

Animals in all three experiments were killed by cervical dislocation on day 4 at $24 \mathrm{~h}$ after the last injection. In Expt 1 and 2, one ovary from each animal was fixed immediately for examination by electron microscopy. The other ovary from animals in Expts 1 and 2, both ovaries from animals in Expt 3, and the uterus of all animals were weighed, and the ovaries were fixed in Bouin's fluid.

\section{Processing and microscopic evaluation of ovaries}

Ovaries were processed for electron or light microscopy by the methods described by Brook and Clarke (1989). The characteristics of the interstitial cells that form the medulla of the ovary were measured as opposed to those in the cortex in which most follicles lie. Interstitial cells occur in the medulla in large areas that are free from follicles, allowing more reliable sampling. Light microscopy examination of ovarian sections stained with haematoxylin and eosin indicated that treatment with gonadotrophins altered the size of the interstitial cells, and the size and shape of their nuclei. The relative size of the interstitial cells was assessed at a magnification of $\times 400$ by counting the number of nuclei per square of a gridded eyepiece graticule. Nuclei in ten squares were counted, and the average was regarded as the best estimate for each animal. The reciprocal of this figure was used as the estimate of the relative size of the cells. Nuclear diameter was taken as the average of two diameters measured at right angles at a magnification of $\times 1000$ using a linear eyepiece graticule. The average of ten nuclei was taken as the nuclear diameter for each wood mouse. This figure was converted to micrometres by calibration with a stage micrometer. Differences in nuclear shape were assessed at a magnification of $\times 400$ by counting the number of smooth-outlined, round or oval nuclei, and the number of nuclei that had an irregular spiky outline in each of ten squares of a gridded eyepiece graticule. The totals for each animal were used as the estimate for the percentage of smooth-outlined nuclei.

Data from Expt 1 and 2 were analysed by ANOVA. Differences between means were examined by the $t$ test. Data for Expt 3 were analysed by paired comparisons using the $t$ test. In all cases, $P<0.05$ was taken to show a statistically significant effect of treatments, or difference between means. Some data had unequal variances, and the statistical analyses in these cases was on measurements transformed to their logarithms.

\section{Results}

\section{Overall response to treatment}

The final body weights did not differ significantly from the initial body weights for any of the treatments. Mean 
final body weights were $10.5 \pm 0.4 \mathrm{~g}, 14.9 \pm 0.3 \mathrm{~g}$ and $16.2 \pm 0.4 \mathrm{~g}$ for Expts 1, 2 and 3, respectively. In Expts 1 and 2 , the vaginas of hormone-treated wood mice became perforate, and the vaginal smears were 'thin' containing a few nucleated or cornified epithelial cells. The vaginas of animals injected with water remained non-perforate. The vaginal smears of all the animals in Expt 3 changed during the 4 months of simulated winter conditions from highly cornified to 'thin' smears. The females that were subsequently treated with eCG and hCG developed smears that contained abundant cornified cells, whereas the smears of animals injected with water remained 'thin'. Treatment of juvenile and adult wood mice with gonadotrophins resulted in a significant increase in ovarian and uterine mass (Tables 1 and 2). Differences between treatment means are statistically significant. In Expt 2, eCG and hCG given alone or in combination to adults, had clear cut effects on ovarian and uterine mass, although there was no augmentation of the effect by administering the two hormones together. The ovarian mass for the adult wood mice in Expt 3 (Table 2) is much greater than the other values because it is for two ovaries. In hormone-treated juveniles and adults, each ovary had 17-18 and 5-9 antral follicles, respectively, which ranged from 490 to $550 \mu \mathrm{m}$ in diameter. In untreated juveniles and adults there were three to four antral follicles per ovary, which had diameters of 300-350 $\mu \mathrm{m}$. In Expt 1, none of the females had corpora lutea. One animal in Expt 2 treated with eCG had two well developed corpora lutea and one animal in Expt 3 treated with a combination of eCG and hCG had 13 well developed corpora lutea. The corpora lutea in these animals were round in outline and 600-700 $\mu \mathrm{m}$ in diameter. The cells of the corpora lutea were round, strongly eosinophilic, 13-16 $\mu \mathrm{m}$ in diameter with no vacuoles in the cytoplasm. The cell nuclei were round or oval, $6-7 \mu \mathrm{m}$ in diameter and were not pyknotic. Three water-treated wood mice in Expt 3 had 14, two and one poorly developed corpora lutea. These corpora lutea were irregular in outline and up to $300 \mu \mathrm{m}$ in diameter. The cells were strongly eosinophilic, up to $9 \mu \mathrm{m}$ in diameter and occasionally contained vacuoles in the cytoplasm. The cell nuclei were 5-6 $\mu \mathrm{m}$ in diameter, had irregular outlines and were often pyknotic. Corpora lutea were not present in any of the other hormone-treated or water-treated females.

\section{Interstitial cells}

Overall, qualitative examination of ovarian sections showed that the interstitial cells of hormone-treated animals had cytoplasm that was more eosinophilic and nuclei that contained less heterochromatin compared with those cells of untreated wood mice. Analysis of variance showed that for the juveniles in Expt 1 there was a significant effect of eCG followed by hCG on the size of the interstitial cells and their nuclei. Mean relative size of the cells and mean nuclear diameter at both hormone doses were significantly greater than in untreated juveniles (Table 1; Fig. 1a,b). In both hormone-treated and untreated animals, nuclei had smooth rather than spiky outlines, although they were more consistently round in the hormone-treated animals (Fig. 1a,b). Similarly, for Expt 2 analysis of variance showed that in adults that received eCG or hCG alone or in combination there was a significant effect of treatments on the relative size of the cells, nuclear diameter and nuclear shape. Mean relative size of the cells and mean nuclear diameter were significantly greater in wood mice that received eCG or hCG alone or in combination than in untreated animals. The percentage of smooth-outlined, round or oval nuclei was significantly greater in hormone-treated animals (Table 2). Similarly, for Expt 3 the $t$ test showed that these three parameters of the cells were significantly greater in the hormone-treated regressed females than in untreated animals. (Table 2; Fig. 1c,d).

Electron microscopy showed that in animals that received eCG or hCG alone or in combination, there was a decrease in the number of lipid droplets and an increase in the smooth membrane content of interstitial cells compared with untreated animals. The lipid droplets were so

Table 1. Mean ( \pm SEM) of ovarian and uterine masses and ovarian interstitial cell characteristics of a single ovary in juvenile wood mice (Apodemus sylvaticus) treated with a combination of eCG and hCC

\begin{tabular}{lcccc}
\hline $\begin{array}{c}\text { Treatments } \\
(\mathrm{n})^{*}\end{array}$ & $\begin{array}{c}\text { Ovarian mass } \\
(\mathrm{mg})\end{array}$ & $\begin{array}{c}\text { Uterine mass } \\
(\mathrm{mg})\end{array}$ & $\begin{array}{c}\text { Relative size of } \\
\text { cell }\end{array}$ & $\begin{array}{c}\text { Nuclear } \\
\text { diameter }(\mu \mathrm{m})\end{array}$ \\
\hline $\begin{array}{l}\text { Untreated } \\
(4)\end{array}$ & $1.7 \pm 0.1$ & $8.4 \pm 0.8$ & $84.3 \pm 7.7$ & $4.2 \pm 0.3$ \\
$\begin{array}{l}10 \text { iu eCG }+ \\
10 \text { iu hCG }\end{array}$ & $9.2 \pm 1.4$ & $55.8 \pm 6.3$ & $177.0 \pm 33.9$ & $6.4 \pm 0.2$ \\
$(4)$ & & & \\
20 iu eCG + & $11.4 \pm 3.7$ & $62.3 \pm 7.9$ & $205.8 \pm 21.9$ & $6.5 \pm 0.2$ \\
$\begin{array}{l}20 \text { iu hCG } \\
(4)\end{array}$ & & & \\
\hline
\end{tabular}

*Sample size. 
Table 2. Mean ( \pm SEM) ovarian and uterine masses and ovarian interstitial cell characteristics for adult sexually mature and sexually regressed wood mice (Apodemus sylvaticus) treated with eCG or hCG alone or in combination

\begin{tabular}{|c|c|c|c|c|c|c|}
\hline & $\begin{array}{l}\text { Treatments } \\
(n)^{*}\end{array}$ & $\begin{array}{c}\text { Ovarian mass } \\
(\mathrm{mg})\end{array}$ & $\begin{array}{l}\text { Uterine mass } \\
\qquad(\mathrm{mg})\end{array}$ & $\begin{array}{l}\text { Relative size } \\
\text { of cell }\end{array}$ & $\begin{array}{l}\text { Nuclear diameter } \\
(\mu \mathrm{m})\end{array}$ & $\begin{array}{c}\text { Smooth:spiky } \\
\text { nuclei }(\%)\end{array}$ \\
\hline \multirow{4}{*}{$\begin{array}{l}\text { Sexually } \\
\text { mature } \\
\text { adults } \\
\text { (one ovary) }\end{array}$} & $\begin{array}{l}\text { Untreated } \\
\text { (5) }\end{array}$ & $2.6 \pm 0.2$ & $20.4 \pm 8.3$ & $214.9 \pm 22.7$ & $5.7 \pm 0.2$ & $14.8 \pm 11.8$ \\
\hline & $\begin{array}{c}10 \text { iu eCG } \\
(5)\end{array}$ & $5.0 \pm 1.4$ & $73.0 \pm 7.5$ & $320.7 \pm 29.4$ & $6.3 \pm 0.1$ & $92.5 \pm 1.1$ \\
\hline & $\begin{array}{c}10 \text { iu hCG } \\
(5)\end{array}$ & $4.1 \pm 0.6$ & $63.6 \pm 3.5$ & $334.2 \pm 22.3$ & $6.3 \pm 0.1$ & $88.9 \pm 4.1$ \\
\hline & $\begin{array}{c}10 \text { iu eCG + } \\
10 \text { iu hCG } \\
\text { (5) }\end{array}$ & $6.8 \pm 1.5$ & $72.4 \pm 3.7$ & $348.9 \pm 45.2$ & $6.5 \pm 0.1$ & $79.3 \pm 9.3$ \\
\hline \multirow{2}{*}{$\begin{array}{l}\text { Regressed } \\
\text { adults } \\
\text { (two ovaries) }\end{array}$} & $\begin{array}{l}\text { Untreated } \\
(4)\end{array}$ & $5.7 \pm 0.8$ & $15.0 \pm 1.7$ & $224.7 \pm 16.9$ & $5.7 \pm 0.1$ & $2.2 \pm 0.2$ \\
\hline & $\begin{array}{c}10 \text { iu eCG + } \\
10 \text { iu hCG } \\
\text { (4) }\end{array}$ & $14.5 \pm 2.4$ & $76.3 \pm 8.3$ & $321.4 \pm 36.1$ & $6.2 \pm 0.1$ & $80.4 \pm 5.2$ \\
\hline
\end{tabular}

*Sample size.

abundant in untreated wood mice that they impinged on the nuclear membrane around its circumference, giving it an irregular shape with protrusions and indentations. This was not observed in the hormone-treated animals.

\section{Discussion}

Wood mice treated with distilled water retained either non-perforate vaginas or 'thin' vaginal smears, whereas gonadotrophin-treated animals developed perforate vaginas and had vaginal smears that contained nucleated or cornified epithelial cells. These changes, together with an increase in the mass of ovaries and uteri of hormonetreated wood mice, and the greater size and number of antral follicles indicate that the gonadotrophins administered were active and produced the expected effects on the reproductive system of the wood mouse. The change from initially highly cornified to thin vaginal smears in the animals exposed to simulated winter conditions indicates that before gonadotrophin treatment the ovaries had progressed to a less active state, as occurs under natural conditions in the field in winter (Baker, 1930).

A small proportion of virgin wood mice from the laboratory stock had a 4-6 day oestrous cycle (Brook, 1984; Clarke, 1985) and corpora lutea were present in at least some virgin females (Brook and Clarke, 1989). As indicated by vaginal smears, other mice in the colony appeared to be in permanent oestrus or in an anoestrous state, or retained non-perforate vaginas for several months despite the fact they were old enough to be sexually mature (Clarke, 1985). Despite the efficacy of the hormones in producing gross changes in the ovaries, uterus and vagina, and in promoting follicular development, only two hormone-treated animals had corpora lutea. The size, shape, cellular and nuclear characteristics of the corpora lutea indicated that they were in a more active secretory state than those of the three untreated wood mice. Among the females subjected to simulated winter conditions, 13 corpora lutea were observed in one hormone-treated animal, whereas in three untreated animals one, two and 14 corpora lutea were observed, respectively. All of these females had ovulated at least once, possibly while passing from the initial sexually mature state to a state in which the ovaries (as judged by the 'thin' vaginal smears) were less active. This quiescent endocrine state may have allowed preservation of successive generations of corpora lutea. In one hormone-treated regressed female, the administered hormone appeared to have activated all 13 corpora lutea that had accumulated. In all three experiments, eCG (with or without hCG) caused appreciable ovarian growth, an increase in the number and the size of antral follicles and uterine enlargement; however, it is possible that during the 3 days of treatment the antral follicles in most females did not develop in a manner that made them competent to respond to the ovulatory stimulus provided by the gonadotrophins. 

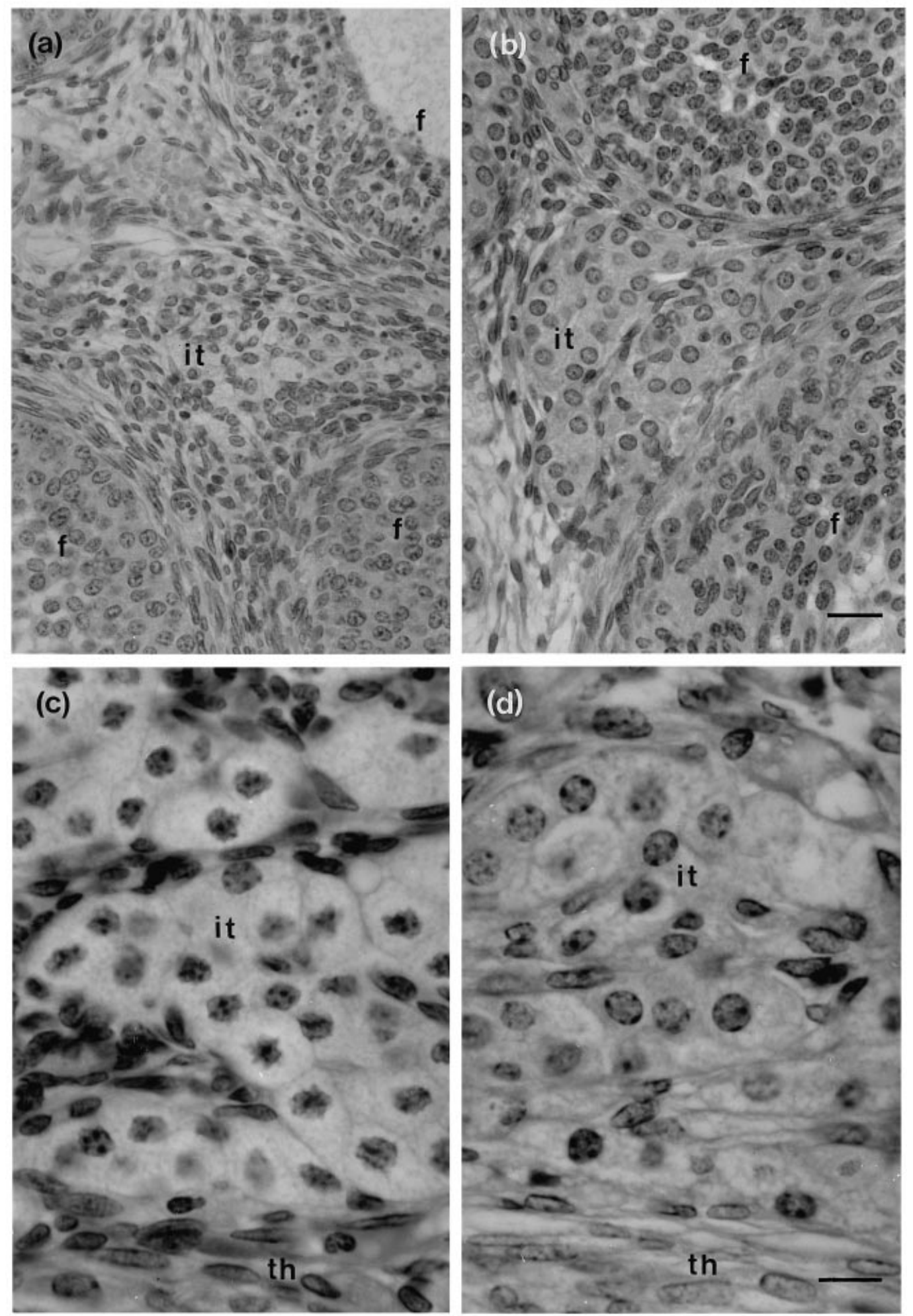

Fig. 1. Ovarian interstitial tissue of wood mice (Apodemus sylvaticus) illustrating the effect of eCG and hCG, administered alone or in combination, on cell and nuclear characteristics. (a) Untreated juvenile; (b) juvenile treated with eCG plus hCG; (c) untreated adult; (d) adult treated with eCG plus hCG. In hormone-treated animals, interstitial cells and their nuclei are larger and in juveniles are more consistently round than in untreated animals. Nuclei of hormone-treated adults are round or oval with a smooth outline, whereas nuclei in untreated animals are irregular and spiky in outline. Ehrlich haematoxylin and eosin stained sections. f: follicle; it: interstitial cells; th: theca externa. Scale bars represent (a,b) $20 \mu \mathrm{m}$ and (c,d) $10 \mu \mathrm{m}$. 
The interstitial gland is a complex population of steroid producing cells of dual origin, which proliferates during the growth and differentiation of the ovaries (Deanesley, 1972; Guraya and Motta, 1980; Erickson et al., 1985; Washenick and Dundar, 1988; Brook and Clarke, 1989). By comparison with the ovaries of untreated animals, eCG and hCG whether administered sequentially, alone or together, induced an increase in the size of interstitial cells and their nuclei in both juveniles and adults. The cell nuclei of juveniles, in both treated and untreated animals, were round or oval in outline, and the nuclear membrane was smooth with no irregularities or spikes. The irregularities and spikes of the nuclear membrane in untreated adult wood mice were not observed in the nuclei of adults given eCG or hCG alone or in combination. This humorally induced change in nuclear shape was particularly apparent in adult wood mice in which the ovaries had progressed to an inactive state as a result of subjecting the animals to simulated winter conditions before treatment with a combination of eCG and hCG. Electron micrographs showed that the lipid droplets were not abundant in the interstitial cells of juveniles (Brook and Clarke, 1989). Electron micrographs of the tissue from untreated adults showed that the lipid droplets were so abundant in the interstitial cells that they distorted the nuclear membrane, whereas in hormone-treated adults there were fewer lipid droplets, which did not impinge on the membrane. It seems likely that the irregularity and spikiness of nuclei in light microscope preparations of untreated adult wood mice are a consequence of the distortion of the nuclear membrane by the abundant lipid droplets.

The histochemical and ultrastructural characteristics of the interstitial cells of the ovary of the wood mouse, including the presence of $3 \beta$-hydroxysteroid dehydrogenase and the occurrence of cholesterol or its esters in the large lipid droplets (Brook and Clarke, 1989), indicates that this tissue produces steroids, as has long been recognized in laboratory animals (Guraya and Motta, 1980; Taya et al., 1980; Silavin and Greenwald, 1982; Erickson et al., 1985). The changes in the cells of juvenile and adult wood mice after gonadotrophin treatment indicate that the cells increased their secretory activity (Guraya and Motta, 1980). Ultrastructural characteristics of interstitial cells are similar qualitatively to those of the luteal cells in the corpora lutea of pregnant wood mice, although the decrease in lipid droplets in interstitial cells after hormone treatment is less marked than that occurring in corpora lutea during pregnancy (Brook, 1984). A combination of eCG and hCG may have caused only a small increase in the synthesis and release of steroid hormones, but the abundance of interstitial tissue indicates that it could contribute significantly to ovarian function. The decrease in the number of lipid droplets and the increase in the smooth membrane content is the basis of the increased eosinophilia of interstitial cells in hormone-treated animals. The importance of gonadotrophins in the regulation of the activity of interstitial cells is well established, and LH, hCG, eCG and possibly prolactin are reported to have a morphogenetic as well as a trophic role (Davies and Broadus, 1968; Carithers, 1976; Guraya and Motta, 1980). Both effects of gonadotrophins occurred in the present study. Changes in cell and nuclear morphology, similar to those described in the current study and which are induced by gonadotrophins have been described in rabbits and rats (Carithers, 1976; Guraya and Motta, 1980; Risma et al., 1997).

Erickson et al. (1985) reported that the LH receptor and $3 \beta$-hydroxysteroid dehydrogenase are tissue specific markers for, and constitutive molecules in, interstitial cells. Both primary and secondary interstitial tissue has $\mathrm{LH}$ receptors (Erikson et al., 1985; Zachow et al., 1993). Although eCG has some LH activity (Stewart and Allen, 1981; Murphy and Martinuk, 1991), it is surprising that treatment of wood mice with hCG did not have a greater effect on the characteristics of the interstitial cells than that seen with eCG alone. eCG can effect a considerable depletion of sudanophilic, cholesterol-positive lipid droplets in interstitial tissue of hamsters, and an increase in plasma concentrations of steroid hormones after treatment with gonadotrophins is brought about by de novo synthesis of progestational steroids, perhaps from the interstitial tissue (Guraya, 1978; Guraya and Motta, 1980). Interstitial cells stimulated by $\mathrm{LH}$ are known to be a source of androgen, which is passed on to follicular granulosa cells where it is aromatized to oestrogen (Erickson et al., 1985; Magoffin and Erickson, 1988). Theca interstitial cells are thus crucial for the development and maintenance of secondary sex characteristics in females, and in other aspects of female reproduction (Guraya and Motta, 1980). Changes in the activity of interstitial tissue may contribute to ovarian dysfunction involving hyperandrogenism and the development of polycystic ovaries (Cara and Rosenfield, 1988; Risma et al., 1997). However, the hormonal regulation of interstitial tissue differentiation and activity is poorly understood, partly because the interstitial cells in a number of laboratory or domestic animals are embedded in connective tissue, which makes it difficult to isolate tissues that do not contain other types of cell (Magoffin and Erickson, 1988). The extensive development of the interstitial tissue in the wood mouse, as also seen in rabbits, provides a model that may allow more precise determination of its control.

The authors are indebted to J. Evans and V. Petts for their care and skill in maintaining the wood mouse laboratory stock, and to S. Milligan and N. Spears for their comments on the manuscript. F. Brook was supported by an SERC research studentship. Part of the work was done while J. Clarke held a Leverhulme Emeritus Research Fellowship.

\section{References}

Baker JR (1930) The breeding season in British wild mice Proceedings of the Zoological Society of London 113-126

Bouin P (1902) Les deux glandes à sécrétion interne de l'ovaire: la glande interstitielle et le corps jaune Revue médicale de l' Est 34 465-472 
Brook FA (1984) Studies of Ovarian Structure and Function in the Wood Mouse, Apodemus sylvaticus DPhil Thesis, Oxford University xii-325

Brook F and Clarke JR (1989) Ovarian interstitial tissue of the wood mouse, Apodemus sylvaticus. Journal of Reproduction and Fertility $\mathbf{8 5}$ 251-260

Cara JF and Rosenfield RL (1988) Insulin-like growth factor I and insulin potentiated luteinizing hormone-induced androgen synthesis by rat ovarian theca-interstitial cells Endocrinology 123 733-739

Carithers JR (1976) Ultrastructure of rat ovarian interstitial cells. III: Response to luteinizing hormone Journal of Ultrastructure Research 55 96-104

Clarke JR (1985) The reproductive biology of the bank vole (Clethrionomys glareolus) and the wood mouse (Apodemus sylvaticus) Symposium of the Zoological Society of London 55 33-59

Davies J and Broadus CD (1968) Studies on the fine structure of ovarian steroid-secreting cells in the rabbit. I. The normal interstitial cell American Journal of Anatomy 123 441-452

Deanesley R (1972) Origins and development of interstitial tissue in ovaries of rabbit and guinea pig Journal of Anatomy 113 251-260

Erickson GF, Magoffin DA, Dyer CA and Hofeditz C (1985) The ovarian androgen producing cells: a review of structure/function relationships Endocrine Reviews 6 371-399

Guraya SS (1978) Recent advances in the morphology, histochemistry, biochemistry and physiology of interstitial cells in the mammalian ovary International Review of Cytology 55 171-245

Guraya SS and Motta PM (1980) Interstitial cells and related structures. In Biology of the Ovary pp 68-85 Eds PM Motta and ESE Hafez. Developments in Obstetrics and Gynecology, Martinus Nijhoff, The Hague

Magoffin DA and Erickson GF (1988) Purification of ovarian theca- interstitial cells by density gradient centrifugation Endocrinology 122 2345-2347

Murphy BD and Martinuk DJ (1991) Equine gonadotropin Endocrine Reviews 12 27-44

Risma KA, Hirshfield AN and Nilson JH (1997) Elevated luteinizing hormone in prepubertal transgenic mice causes hyperandrogenemia, precocious puberty and substantial ovarian pathology Endocrinology 138 3540-3547

Silavin SL and Greenwald GS (1982) In vitro progesterone production by ovarian interstitial cells from hypophysectomized hamsters Journal of Reproduction and Fertility 66 291-298

Stewart F and Allen WR (1981) Biological functions and receptor binding activities of equine chorionic gonadotrophin Journal of Reproduction and Fertility 62 527-536

Taya K, Saidapur S and Greenwald GS (1980) Interstitium: site of steroid synthesis in the ovary of the long-term hypohysectomized hamster Biology of Reproduction 22 307-318

Washenick KJ and Dunbar BS (1988) Identification and characterization of an abundant ovarian interstitial gland protein associated with sexual maturity in rabbits Endocrinology 122 1663-1671

Zachow RJ, Tash JS and Terranova PF (1993) Tumour necrosis factor- $\alpha$ attentuation of luteinizing hormone-stimulated androstenedione production by ovarian thecal interstitial cells: inhibition at loci within the adenosine $3^{\prime} 5^{\prime}$-monophosphate-dependent signalling pathway Endocrinology 133 2269-2276

Received 4 April 2000.

Accepted 4 August 2000. 